\title{
A walk down memory lane
}

Some may have noticed that all the back-dated issues of the South African Journal of Sports Medicine have been digitally converted and loaded onto the journal website (http://www.sajsm.org.za/index. $\mathrm{php} / \mathrm{sajsm} /$ issue/archive). This was facilitated by the African Journal Archive Project (http://www.ajarchive.org), which is a retrospective digitisation project aimed at building a digital archive of journals published exclusively in Africa and about Africa. The project is funded by the Carnegie Corporation and managed by Sabinet Online. This was done at no cost to the South African Sports Medicine Association (SASMA) and was supported by the publishers of our journal, the Health and Medical Publishing Group, who then loaded the digitally converted journals onto the website.

The journals go back to 1981 and provide a fascinating account of how sports medicine in South Africa started and evolved. The first edition of the Journal in 1981 had a foreword by Dr Piet Koornhof, the then Minister of Sport and Recreation (see page 5 of the current issue of SAJSM). In the foreword he mentioned that medical practitioners should have closer contact with physical education practitioners. Prophetic words indeed, given that physical education was dumped from schools soon after that and is still trying hard to make a comeback into the curriculum.

In the second edition of the Journal in 1981, Tim Noakes published a paper showing that marathon runners were not immune to coronary heart disease (see page 7 of the current issue). This was contrary to the prevailing belief of the time and was one of the pioneering papers that legitimatised the discipline of sports medicine. This paper received international recognition and established Noakes as a creative paradigm buster. In the same edition was a paper that described first aid for the collapsed player on the field. The collapse was attributed to one of 5 causes: 'heat illness, impact to celiac plexus, head and neck injury, diabetic shock or epilepsy?

The fifth edition of the Journal in 1981 is a great issue for making comparisons with topical issues of 2013. For example, there is a paper on concussion. Although the paper lacks the detail about concussion management described in the latest Zurich Concussion Consensus that has just been released, ${ }^{[1]}$ it is remarkable in that the advice offered therein for managing concussed players is not too far removed from what would be regarded as best practice today. There is also an article in the fifth edition that describes the comments of an American doctor, John Chase, in reference to rugby (see page 22 of the current issue): 'if a player is hit by a $115 \mathrm{~kg}$ forward, and knocked senseless, the trainer will rush onto the field with a little sponge in a bucket of water and whether your teeth are knocked out, your arm is broken, or you have a concussion, you get the magic sponge. He stated that the days of the 'magic sponge' are over, and each rugby team needs its own doctor! Once again, prophetic words considering that rugby would only become a professional sport nearly 15 years later!

Also in this edition was an article calling for greater scientific involvement in managing the psychology and fitness of rugby players. It was argued in the manuscript that while many hours are spent at rugby practice, relatively little time was devoted to achieving suitable levels of fitness. Reference was also made to the misconception that players should have a protein intake of steak and eggs before a match. The author also referred to the halftime routine of eating half an orange. He concluded that there needed to be a greater scientific involvement in rugby to manage the wellbeing of players; it is a pity that he did not have a glimpse into the future, 30 years later, where he would have seen the BokSmart website, where the 'A to Z' of player welfare, including their nutrition, is discussed.

Going back in time can be enlightening for two reasons. Firstly, it shows the progress that has been made in the discipline of sports medicine. Secondly, it identifies the pioneers who courageously started the discipline and laid the foundation for how sports medicine is currently practised. Without their bold beginning, sports medicine would not be where it is today.

This first edition of the Journal for 2013 has a rugby theme. Enjoy the read!

\section{Mike Lambert \\ Editor-in-Chief}

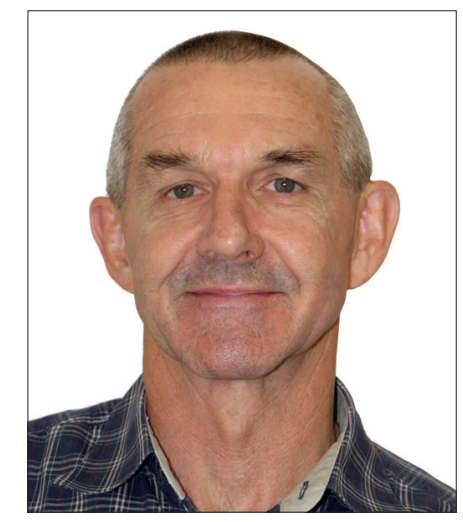

1. McCrory P, Meeuwisse WH, Aubry M, et al. Consensus Statement on Concussion in Sport: The 4th International Conference on Concussion in Sport held in Zurich, November 2012. Br J Sports Med 2013;47(5):250-258. [http://dx.doi.org/10.1136/ bjsports-2013-092313]

S Afr J SM 2013;25(1):2. DOI:10.7196/SAJSM.463 